\section{Genetic background of OCD}

Erich Bruns

Institut für Tierzucht und Haustiergentik, Universität Göttingen

\section{Introduction}

The longevity of sport horses is one of the most relevant parameters in breeding. Wallin et al. (2000) report that $60 \%$ of riding horses have to stop their sport career due to leg problems. Out of these osteochondrosis is one of the major, economically important problems. One manifestation of osteochondrosis is osteochondrosis dissecans (OCD) which is seen as a disturbance in endochondral ossification. Another manifestation of osteochondrosis is subchondral cystic lesion. OCD has been described in a large number of different joints, mostly affected are fetlock joints, hocks and stifles. The current presentation will focus on genetic results in the literature, most recent studies and the experience from the interdisciplinary study with warmblood foals reared under practical field conditions as used on breeding farms in Lower Saxony.

\section{Definition of osteochondrosis / measures}

Osteochondrosis (OC) in the horse is a disease charaterised by the disturbance of the normal differentition of chondrocytes in the growing cartilage, leading to the disturbance in the endochondral ossification, a process in which cartilage is mineralised and transformed into bone. Cracks and fissures occurre in the degenerated and necrotic parts of the cartilage. This leads to formation of cartilage flaps and eventually to loose bodies called chips or joint mice. So this type of manifestation is also called osteochondrosis dissecans (OCD), which has been described in a large number of different joints, mostly affected are fetlock joints, hocks and stifles and is usually observed by macroscopic inspection or by examination of $x$-rays. The examination of $x$-rays normally leads to a scoring system which encompasses the severity of lesions visible in x-rays. The clinical manifestation of this disease leads to a secondary chronic degenerative joint disease in adult animals. The aetiology of OC appears to be multifactorial, affected by exercise regime, growth rate and hereditary factors. Nutritional factors and endocrinal effects seemed to have a role in the pathogenesis, too. It seems that there is not a strict borderline between horses with and without osteochondrosis, it may be age dependent and the severity may relate to the location and the number of joints examined.

\section{Frequency}

The frequency of osteochondrosis as reported in the literature varies substantially depending on the type and size of horse populations sampled, the scale of measurement, the num- ber of locations studied, the definition of OC, and the age of horses examined (Ricard 2004).

In trotters the frequency of OCD in the hock measured on a $0 / 1$-scale is $10.5 \%, 14.3 \%$ and $14.5 \%$ as reported by Philipsson et al. (1993), Grondhal et al. (1993) and Ricard (2004).

The frequency of OCD summarised over several locations considering the degree of severity may give a more sensitive measure and provide a way of testing the assumption of the same genetic origin of $\mathrm{OC}$ at different joints. Most authors, Philipsson et al (1993), Grondhal et al. (1993), Ricard et al. (2002), and Willms et al. (1996) found low correlations between locations.

Ricard et al. (2002) reported the frequency of OCD on hock and fetlock to be $35 \%$, but when adding more locations like foot, hoof, and carpus the frequency was $63 \%$. The frequency of radiographic findings on $\mathrm{OC}$ in foals examined in the field study of Lower Saxony was 19.5\%, 11.1\%, and 7.2\% in the fetlock, hock, and stifle joint, respectively (Arnan 2004), but summarised over all three locations the frequency was $32.6 \%$.

The frequency of $\mathrm{OC}$ also depends on the age of horses examined. When the horses were two years of age the frequency of the OC findings in the German field study was $26.2 \%$ summarised over all three joints, and 16.6\%, 10.4\%, and 2.2\% in the fetlock, hock, and stifle, respectively (Arnan (2004). Similarly, Stock et al. (2004) reported frequencies of osseous fragments in fetlock and hock joints of warmblood horses at auction to be $20.8 \%$ and $9.1 \%$.

The German field study showed a low repeatability of $O C$ findings between foals and two years old horses. So, $46 \%$ of the $\mathrm{OC}$ findings in the fetlock of foals could not be verified in the 2 -ys-old, but $30 \%$ of the findings in the 2 -ys-old were not identified in foals. But, in the hock OC was identified with a high correlation between the two age groups (Arnan 2004).

In Coldblood foals (Süddeutsches Kaltblut) Wittwer et al. (2004) estimated frequencies of OC in the fetlock and hock as $53.5 \%$ and $16.5 \%$, the respective frequencies of OCD were $36.0 \%$ and $0.5 \%$.

\section{Heritability}

The osteochondrosis appears to be affected by a number of environmental factors such as growth, exercise, and nutrition. Hereditary factors seem to play an important role as well; their size normally described by the estimates of the heritability varies substantially due to the same factors influencing the above mentioned frequency, and in addition due to the type of scale (discrete vs binary) and the statistical model used in estimation (sire vs animal model) (Ricard 2004).

The heritability of osteochondrotic lesions varies from 0.08 to 0.52 and from 0.12 to 0.19 in the hock and fetlock of trotters, respectively (Philipsson et al. (1993), Sandgren et al. (1993), Schougaard et al. (1987), Grondahl et al. (1990). Philipsson (1999) shows that the mean frequency of OCD of 
progenies of sires in trotters varies between $0 \%$ and $24 \%$. In riding horses heritability estimates of osteochondrosis in the hock vary between 0.01 and 0.34 (KWPN (1994), Winter (1995), Willms (1998), Ricard et al. (2002) Pieramati et al. (2003)).

In the latest German field study Schober (2003) estimated heritabilities as 0.15 and 0.23 for $\mathrm{OC}$ in the fetlock and hock of foals, respectively. The corresponding estimates for twoyears old horses were 0.15 and 0.42 , and for their mares were 0.10 and 0.21 , respectively.

The study using data on Hanoverian auctioned horses gave estimates of heritabilities as 0.17 and 0.32 for $\mathrm{OC}$ in the fetlock and hock (Stock et al. 2004).

The genetic relation between the $\mathrm{OC}$ findings in the fetlock and hock is negative: if there were osteochondrotic lesions in the fetlock identified, there were none found in the hock of the same foal. Only very few foals (3\%) had OC findings in both joints. Therefore $\mathrm{OC}$ in the fetlock and in the hock seem to depend on a different aetiology and genetic background (Schober 2003).

Ricard (2004) reports that trotters show higher estimates of heritability in $\mathrm{OC}$ of the hock than riding horses, but there is great variablility in the estimates.

Another way of studying the genetic background of osteochondrosis is looking at genetic subgroups of riding horses. Schober (2003) showed differences in the OC frequency, the lowest was 0.24 and the highest was 0.41 , between the five subgroups defined according to the genetic origin of the sires of the examined foals. Generally, thoroughbreds are considered as showing the highest frequencies in OC.

\section{Genetic relationships}

The genetic relation between the OC-predisposition and the performance in sports is relevant in horse breeding. Philipsson (1999) indicates that in trotters there is no relation between a single OCD finding and the number of starts, the frequency of top placings and earnings. Horses with multiple OCD findings were inferior.

In riding horses Schober (2003) found no relationship between osteochondrosis in foals and breeding values of their sires in dressage and jumping. This is in agreement with the studies by Winter (1995) and Willms (1998). Selection for improving dressage and jumping in warmblood populations will therefore not increase the frequency of OC.

Also, the genetic relation between the $\mathrm{OC}$-predisposition and the conformation of foals seems to be non-existent or very low (Schober 2003).

\section{Molecular genetics}

The study for identifying genetic marker for $\mathrm{OC}$ is still ongoing. There is hope that ongoing projects will identify more genetic marker, some may be helpful in identifying QTLs so that selection against $\mathrm{OC}$ will be supported by molecular genetics and may lead to procedures like marker assisted selection (Löhring and Distl 2004). But the only molecular result on $O C$ in livestock was found in pigs with no significant evidence of QTL for OC, although some markers were detected for scores of leg weakness (Lee et al. 2003).

\section{Conclusion}

Selecting against $\mathrm{OC}$, i.e. reducing the frequency of osteochondrotic lesions, separately for those in the fetlock and in the hock, is possible by applying regular genetic principles. But attention has to be given to the relative economic weight of all selection criteria, performance and health traits, applied in the selection process. Existing breeding programmes have to be adjusted for considering performance and health traits simultaneously in selection.

Busche and Bruns (2005) shows the effectiveness of selection against $O C$ in warmblood populations in relation to the underlying genetic model of OC. Applying selection principles will effectively reduce $O C$ frequencies, but at the cost of reduced progress in performance traits such as dressage and jumping. Osteochondrotic lesions in horse populations as identified by radiographic means is not a disease by itself, but may lead to clinical findings at a later stage. Therefore further studies should concentrate on improving the scale of measurement for optimising statistical analyses the relation between clinical and radiographic findings the impact of $\mathrm{OC}$ on the length and intensity of sport activities.

\section{References}

Arnan P. und Hertsch B. (2004): Röntgenologische Untersuchungen zur Erfassung der Osteochondrosis dissecans im Fessel-, Sprungund Kniegelenk im Vergleich vom Fohlen zum Zweijährigen. Göttinger Pferdetage, Tagungsband, 115-124

Busche M. and Bruns E. (2005): Evaluation of breeding strategies against osteochondrosis $(\mathrm{OC})$ in warmblood horses. 56th Annual Meeting of European Association of Animal Production, Uppsala, Sweden

Grondahl A. M. and Dolvik N. L. (1990): Heritability estimations of osteochondrosis in the tibiotarsal joint and of bony fragments in the metacarpo- and metatarsophalangeal joints of Norwegian Standardbred trotters. 41th Annual Meeting of European Association of Animal Production, Toulouse, France

Grondahl A. M. and Dolvik N. L. (1993): Heritability estimations of osteochondrosis in the tibiotarsal joint and of bony fragments in the palmar/plantar portion of the metacarpo and metatqarsophalangeal joints of the horse. Journal of the American Veterinary Medical Association 203, 101-104

Königliches Warmblut Pferdestammbuch in den Niederlanden, KWPN (1994): The frequency and heredity of navicular disease, sesamoidosis, fetlock joint arthrosis, bone spavin, osteochondrosis of the hock. A radiographic progeny study.

Lee G. J., Archibald A. L., Garth G. B., Law A. S., Nicholson D., Barr A. and Haley C. S. (2003): Detection of quantitative trait loci for locomotion and osteochondrosis-related traits in Large White $x$ Meishan pigs. Animal Science 76, 155-165

Löhring K. and Distl O. (2004): Entwicklung eines genomweiten Markersets für die Aufdeckung von QTL beim Pferd. Göttinger Pferdetage, Tagungsband, 163-172

Philipsson J., Brendov E., Dalin G. and Wallin L. (1998): Genetic aspects of diseases and lesions in horses. World Conference on Genetics applied to Livestock Production, Armidale, Australia 24, 408-415 
Philipsson J., Andreasson E., Sandgren B., Dalin G. and Carlsten J. (1993): Osteochondrosis in the tarsocrural joint and osteochondral fragments in the fetlock joints in standardbred trotters. I. Heritability. Equine Veterinary Journal Supplement 16, 38-41

Philipsson J. (1999): Genetische Aspekte von Erkrankungen beim Pferd. Göttinger Pferdetage, 11-22

Pieramati C., Pepe M., Silvestrelli M. and Bolla A. (2003): Heritability estimation of osteochondrosis dissecans in Maremmano., Livestock Production Science 79, 249-255

Ricard A., Valette J. P. and Denoiy J. M. (2002): Heritability of juvenile osteo-articular lesions of sport horses in France. 7th World Congress on Genetics Applied to Livestock Production, Montpellier, France

Ricard A. (2004): Genetic background of osteochondrosis. 55th Annual Meeting of European Association of Animal Production, Bled Slovenia

Sandgren B., Dalin G. and Carsten J. (1993): Osteochondrosis in the tarsocrural joint and osteochondral fragments in the fetlock joints in standardbred trotters. I. Epidemiology. Equine Veterinary Journal Supplement 16, 31-37

Schougaard H., Falk-Ronne J. and Philipsson J. (1987): Osteochondrosis in the tibio-tarsal articulation of trotters and ist disposition. 38th Annual Meeting of European Association of Animal Production, Lisbon, Portugal

Stock K. F., Hamann H. and Distl O. (2004): Genetische Beziehungen zwischen röntgenologischen Gliedmaßenbefunden und dem Einsatz der Pferde im Reitsport. Vortragstagung der Deutsche Gesellschaft für Züchtungskunde, Rostock

Van Weeren P. R. and Brama P. A. J. (2003): Equine joint disease in the light of new developments in articular cartilage research. Pferdeheilkunde 19, 336-344
Wallin L., Strandberg E., Philipsson J. and Dalin G. 2000): Estimates of longevity and causes of culling and death in Swedish warmblood and coldblood horses. Livestock Production Science 63, 275-289

Willms F., Roehe R. and Kalm E. (1996): The importance of radiographical investigations of bone diseases in breeding sport horses. 47th Annual Meeting of European Association of Animal Production, Lillehammer, Norway

Willms F. (1998): Genetische Analyse von Merkmalskomplexen der Reitpferdezucht unter Berücksichtigung von Gliedmassenveränderungen. Dissertation, Christian-Albrechts-Universität Kiel

Winter D. (1995): Genetische Disposition von Gliedmassenerkrankungen bei Reitpferden. Dissertation, Georg-August-Universität Göttingen

Wittwer C., Bönecker C., Hamann H. and Distl O. (2004): Genetische Analyse der Osteochondrose beim Süddeutschen Kaltblut. Vortragstagung der Deutsche Gesellschaft für Züchtungskunde, Rostock

E. Bruns

Institut für Tierzucht und Haustiergentik

Universität Göttingen

ebruns@gwdg.de 